\title{
Divine Universal Causality and the Particular Problem of Hell: A Quiescence Solution
}

\author{
ADAM WOOD \\ Wheaton College, USA \\ adam.wood@wheaton.edu \\ ORCID: 0000-0001-7288-4886
}

\begin{abstract}
I call the Particular Problem of Hell (PPH) the problem of explaining why God allows a certain set of created persons to populate hell, as opposed to allowing some other set of created persons to do so. This paper proposes a solution to PPH on behalf of proponents of Divine Universal Causality (DUC) - the view, roughly, that God causes everything distinct from himself to exist at any time it exists. Despite initial appearances, I argue, proponents of DUC can adopt a version of the popular approach to the Problem of Hell sometimes called the Choice Model. My proposal is based upon Eleonore Stump's Thomistically-inspired notion that our wills can enter a state of "quiescence" with respect to a given option. While proponents of DUC will, I argue, most likely find Stump's own quiescence-based solution to PPH unacceptable, there is a way of modifying her approach that renders it compatible with God's causing everything distinct from himself, including the free choices of his creatures.
\end{abstract}

Keywords: Theodicy; Predestination; Reprobation.

Suppose you think that some but not all persons will forever occupy hell, at least in part because of certain sinful choices they have freely made. Suppose, furthermore, that you believe in Divine Universal Causality 
(DUC), the view that, as W. Matthews Grant has recently put it, "Necessarily, for any entity distinct from God, God directly causes that entity to exist at any time it exists" (Grant 2019, 4). In that case, it might appear that the most popular contemporary approach to the Problem of Hell, what Jonathan Kvanvig calls "the Choice Model" (Kvanvig 2011, chaps. 1-3), is unavailable to you. According to Kvanvig's version of the Choice Model and most others, persons occupy hell in part because of sinful choices they've freely made, and God could not have prevented these choices without impinging the creatures' freedom. Yet if DUC is true, then whatever free choices we make are, themselves, caused by God, including sinful ones. It might seem, then, that by refraining from causing some or all sinful choices, God could have avoided any persons occupying hell. Explaining why he didn't do so in general is a thorny problem, to be sure. But in addition to this "General Problem of Hell" (GPH), as I will call it, there is also a different, narrower problem, namely explaining why one particular set of persons ends up occupying hell as opposed to some other set. I call this latter issue the "Particular Problem of Hell" (PPH). The focus of this paper is examining how proponents of DUC might address it.

The Choice Model dispatches both GPH and PPH easily in one fell swoop. God allows hell in general because he wanted some of his creatures to be free, and couldn't prevent some free creatures from choosing to be forever separated from him, which is part of what it means to occupy hell. Only those persons occupy hell, furthermore, whom God could not prevent from making the sinful choices that are at least partially responsible for their damnation. On DUC, however, God causes any choices we make, including any sinful choices. So we might wonder why he causes one particular set of persons to make sinful choices that result in their occupying hell, as opposed to causing some other set of persons to do so. If his decision to cause sinful choices in some particular set of persons is arbitrary, this might well appear unfair and hence unjust on his part.

In this paper I suggest a way that proponents of DUC might avoid charges of arbitrariness, unfairness or injustice in responding to PPH by drawing upon Eleonore Stump's Thomistically-inspired suggestion that in ad- 
dition to willing for or against a given option, the will may also "turn itself off," entering a state of "quiescence" with respect to that option (Stump 2001, 139-41 and 2003, chap. 13). In this paper's first section, I explain further the contours of $\mathrm{PPH}$, especially as it presents itself to proponents of DUC. In the second section I explain how Stump's appeal to the notion of quiescence might appear to provide a response to $\mathrm{PPH}$, and why this sort of response is unavailable to proponents of DUC. In the last section I develop a modified version of Stump's quiescence-based Choice Model that proponents of DUC might accept, and defend it against a series of objections.

\section{Divine Universal Causality and the Particular Problem of Hell}

To explain PPH further, especially as it presents itself to proponents of DUC, it will be helpful to rely on a few traditional theological terms: predestination, reprobation, and merits. No doubt there are diverse opinions in the theological tradition about how best to understand these terms, but I will use them as follows. By the first, I mean God's providential guidance of the lives and decisions of certain created persons such that they ultimately achieve everlasting happiness. If God refrains from guiding certain created persons in this way, such they ultimately fail to achieve everlasting happiness, this I will call reprobation. Finally, merits are simply morally valuable features of created persons on the basis of which they might be said to deserve everlasting happiness.

With this terminology in place, we can understand $\mathrm{PPH}$ as a matter of navigating an apparently inconsistent set of four propositions:

(1) Predestination and reprobation cannot be based upon foreknown merits.

(2) If predestination and reprobation aren't based upon foreknown merits, then they're arbitrary.

(3) If predestination and reprobation are arbitrary, then they're unjust.

(4) Predestination and reprobation aren't unjust. 
The first proposition, put another way, claims that God's reason for predestining those whom he predestines and reprobating others cannot be that he foreknows that certain persons will accrue certain merits while others won't. I'll explain shortly below why I think proponents of DUC are committed to this claim. For now, it will be helpful to note that in the Christian tradition even those who would reject DUC might nevertheless be committed to (1) so as to avoid the heresy of Pelagianism. To avoid Pelagianism, it is often thought, any meritorious features of created persons must be the results of God's grace. But if the presence or lack of merit depends on whether or not God offers us grace, then seemingly whether God predestines or reprobates us cannot be based upon foreknowledge of merits. The other three claims, by my lights, enjoy strong intuitive support. If God doesn't base his decisions to predestine or reprobate on the presence of certain morally valuable features of created persons, then it's hard to see what other relevant factors he might base these decisions on. And if his decisions aren't based on anything relevant at all, then seemingly they're arbitrary. Arbitrarily allotting everlasting happiness to some but not all, however, intuitively seems unfair, and hence unjust. But if God is necessarily morally perfect, as is usually supposed, then his decisions to predestine or reprobate cannot be unjust. Since claims (1)-(3) jointly imply the denial of (4), propositions (1)-(4) taken as a whole are apparently an inconsistent set. Denying (4) seems like an option unavailable to theists, who will wish to insist on God's impeccability, include his perfect justice. So which of (1)-(3) can proponents of DUC reject?

Not (1), for reasons similar to the anti-Pelagian considerations I mentioned above. According to proponents of DUC, it is not just meritorious features of created persons that must depend on divine activity, but anything created whatsoever. Again, DUC holds that for any entity distinct from God, God directly causes that entity to exist at any time it exists. That goes for any meritorious choices, acts or habits that we might come to possess. If God must cause these features of created persons in order for them to exist in the first place, then seemingly he cannot also base his decisions to predestine or reprobate on his foreknowledge of their presence. 
Denying (3) is a possibility that some Christian theologians of the past have seemed willing to embrace. In Romans 9:20-23 Paul writes:

But who are you, $\mathrm{O}$ man, to answer back to God? Will what is molded say to its molder, "Why have you made me like this?" Has the potter no right over the clay, to make out of the same lump one vessel for honorable use and another for dishonorable use? What if God, desiring to show his wrath and to make known his power, has endured with much patience vessels of wrath prepared for destruction, in order to make known the riches of his glory for vessels of mercy, which he has prepared beforehand for glory.

One might interpret this passage as conceding that predestination and reprobation are arbitrary and unfair, but denying that they are unjust, for at least two reasons. First, just as the potter doesn't owe any particular shape to his clay, neither does God owe everlasting happiness to anyone. Accordingly, it isn't unjust if he doesn't grant everlasting happiness to some, even if he refrains from granting it for no particular reason. Second, if it is very good for God to predestine some and reprobate others in general, and if there is no non-arbitrary way for him to accomplish this, then the goodness of predestining and reprobating in general might outweigh the badness of doing so arbitrarily and unfairly. So much so, perhaps, that his decision to arbitrarily select some but not all for everlasting happiness cannot be considered unjust overall. But Paul's words about "making known" God's power and glory might appear to indicate one good reason he has for reprobating some: so that he can manifest his wrath at the sins due to which, at least in part, they end up in hell. Perhaps this chance to make known his anger toward sin is such a great good that enacting it outweighs on the scales of justice the unfairness of arbitrarily selecting some for reprobation. Thomas Aquinas and Jonathan Edwards, among others, seem to embrace reasoning like what I've just described. Aquinas, for instance, compares God to a builder grasping some stones out of a pile for the top of a wall he is building and other stones for the bottom (Summa theologiae [ST] 1a.23.5 ad 3 and Epistolam Pauli ad Romanos lectura 9.4.788). Beyond the fact that the builder's plan re- 
quires some stones at the top and some at the bottom, there is no reason why certain stones end up in one place and others elsewhere. Nevertheless, I consider the denial of (3) a sort of "bullet-biting response" to the $\mathrm{PPH}$. If God had the option of predestining everyone, then it is difficult to see what good was achieved by making known his power, glory, anger at sin or whatever else through reprobation, as opposed to doing so by some other means, particularly if reprobating some required his acting arbitrarily and unfairly.

The solutions to PPH upon which I'll focus in the remainder of this paper are best seen as efforts to reject (2). In the following section I'll discuss a proposal of Stump's that might easily be adapted into a response to $\mathrm{PPH}$, maintaining that while (1) is correct - predestination and reprobation cannot be based upon foreknown merits - nevertheless they can be based upon foreknown quiescence in the wills of sinners who cease actively resisting God's grace. As I'll explain, proponents of DUC will most likely find Stump's version of this proposal unacceptable, since it assumes that God is unable to move a sinner's will from a state of active resistance to one of quiescence. Nevertheless, I'll argue in the final section, a modified form of Stump's proposal might indeed render it compatible with DUC and provide its proponents with a response to PPH that avoids claiming that God acts arbitrarily.

\section{Stump's Quiescence-Based Choice Model}

Stump initially suggested the notion of quiescence as a possible solution to a problem she sees as confronting Augustine in his later work. As Stump notes, in Augustine's relatively early De libero arbitrio 3.18-19 he seemingly maintains that while human persons are incapable of morally upright first-order acts of will apart from God's gracious assistance, God offers grace to all and only those in whom is present a higher-order act of willing to receive it. Even in his later anti-Pelagian works Augustine appears to uphold this same basic stance - Stump 2001, 134 cites De natura et gratia 47.81 as an example. In his later works, however, Augustine makes abundantly clear that the higher-order act of willing to receive God's grace 
is itself also dependent on grace; God must cause it as well (see De correptione et gratia 2.3 and De spiritu et littera 31.53-34.60, both of which Stump 2001, 137 cites, along with De gratia et libero arbitrio [DGLA] 7.17 and 14.28 and De praedestinatione sanctorum [DPS] 2.3). The question, then, as Augustine saw, is why God causes in some a higher-order act of willing for God to reform their unruly desires, while causing no such higher-order act in others. As Stump reads him, Augustine ultimately concluded that he had no good answer. She quotes De dono perseverantiae 8.18, where Augustine responds to the question why God punishes some and not others, despite knowing that his grace causes good choices or deeds in anyone, "I confess I can find no answer to make" (Augustine 1999, 201). Augustine, in other words, sees no good answer to the question that PPH raises (see also DGLA 23.45 and DPS 8.14-15). But Stump reckons that there is, in fact, an answer available to Augustine even given his staunch anti-Pelagianism, provided he is willing to accept that in addition to willing for or against a given option, the will may also simply turn itself off with respect to that option. Stump calls the will's simply ceasing to act with respect to a given option "entering a state of quiescence," and thinks she finds Aquinas endorsing the idea at ST 1a2ae.9.1 and 10.2.

Whether she is correct on not in her interpretation of Thomas, here is how she thinks accepting the notion of quiescence in the will might provide Augustine a solution to PPH. I may will to receive grace from God, or I may will to reject it. I may also, however, simply cease willing one way or another when it comes to receiving grace. To cease willing in this latter way is to enter a state of quiescence with respect to the option in question (receiving grace). Now while a created person's willing to receive grace is an act that is, itself, dependent on God's grace as its cause, their entering a state of quiescence isn't an act at all. Accordingly, even while maintaining his anti-Pelagian insistence that the higher-order act of willing for God to reform our desires is itself caused by God, Augustine could maintain that it is within our power to cease rejecting God's grace by entering a state of quiescence with respect to that option. As Stump puts it, "the will's lapsing into quiescence is not itself another act of will, any more than ceasing to walk east is another act of walking. But since the laps- 
ing into quiescence is not an act of will at all, it can hardly be considered a good act. So ... Pelagianism is warded off" (Stump 2003, 402). If we enter a state of quiescence with respect to receiving God's gracious assistance, Stump suggests, God will in fact provide the grace we need to request his aid in further reforming our moral character. If, however, we continue obstinately willing to reject grace, God will not provide it. Now, while Stump never as far as I know applies the notion of quiescence directly to questions regarding predestination or reprobation, it is clear how her quiescencebased proposal on Augustine's behalf might be adapted as a solution to $\mathrm{PPH}$. It is true, Stump might say, that predestination and reprobation cannot be based upon foreknown merits, since any meritorious features of created persons are dependent on God's grace as their cause. Nevertheless, she might say, God's choices to predestine or reprobate needn't be arbitrary, but might be based rather on whether or not a creature persists in rejecting God's grace. God predestines all and only those who do not prevent him from doing so by persisting in a state of active resistance to his aid. Adapted this way, Stump's proposal might be viewed as offering a sort of Choice Model in response to the Problem of Hell in general, and to PPH in particular.

As attractive as Stump's proposal might be, nevertheless, it seems unlikely to me that proponents of DUC could accept it. That is because, on DUC, the choice on the part of unrepentant sinners to persist in rejecting God's gracious assistance and predestination must itself be caused by God. Likewise, for sinners to cease resisting grace requires such that their wills enter a state of quiescence requires that God cease causing their acts of resistance. If these matters are so, however, then the questions reemerge why God would cause any sinful choices to begin with, or cause certain sinners to persist in actively resisting grace, while ceasing to do so in the case of others whom, ultimately, he predestines.

As far as I can tell, Stump's own answers to the questions would be that God cannot prevent sinners from making sinful choices, nor from persisting in resisting grace should they choose to do so. At several points she states baldly that in her estimation even an omnipotent entity like God cannot "make" a person freely will anything (see Stump 1985, 406; 
1986, 194-95; 1988, 411-412). And in at least one passage she appears to suggest that God's causing a created person's will to occupy any given state would involve coercion incompatible with freedom (Stump 2003, 506-7 n. 11). Nevertheless, Stump argues elsewhere that God can sanctify sinners by reforming their lower-order desires provided they already have a higher-order desire that he do so (Stump 1988). In fact, as her suggestion on Augustine's behalf makes clear, she thinks God can himself cause in created persons a higher-order desire for moral reformation provided that the creatures have ceased actively resisting his aiding them in this way. What Stump evidently believes God cannot do, however, is prevent created persons from sinning in the first place, or to bring it about that a sinner in a state of active resistance should repent.

It is not altogether clear to me why Stump holds these views, but it does seem likely that proponents of DUC must reject them. According to DUC, again, God directly causes the existence of any entities distinct from himself at any time they exist. Assuming, then, that the sinful choices of created persons are entities distinct from God, he directly causes them as well. Hence, unless proponents of DUC want to maintain that God for some reason had to cause sinful choices, they must admit that he could refrain from doing so, and that if he so refrains then created persons will not sin. It was an option available to God, then, to bring about a world full of free creatures who never sin. Or, alternatively, it was an option available to bring about a world full of creatures who sin, yet repent before the end of their lives. Either way, it seems likely that proponents of DUC must accept, against what Stump supposes, that God could have predestined everyone, and didn't have to reprobate anyone. If that is so, however, then for proponents of DUC Stump's proposal as it stands can solve neither the general problem of why God reprobates anyone at all, nor the Particular Problem of Hell: providing some rationale for God's decisions to reprobate the particular creatures he does. In the following section, however, I'll outline a modified quiescence-based Choice Model that I think proponents of DUC might indeed accept. If successful, this model would provide them a response to $\mathrm{PPH}$, though not an answer to the question why God permits hell to be occupied in general. 
Before launching into it, however, let me pause briefly to consider whether proponents of DUC might maintain that God had to cause sinful choices after all. Molinists might conceivably claim that, given the counterfactuals of creaturely freedom, God had to cause sinful choices if he wanted to make any free creatures at all. Perhaps given these counterfactuals it wasn't, in fact, open to God to bring about a world full of free creatures who never sin, or full of sinful creatures all of whom repent before the end of their lives. Molinists might then respond to GPH just as the Choice Model does; God allows hell because he couldn't avoid it without impinging creaturely freedom. As for PPH, Molinists might again rely on the counterfactuals of creaturely to engineer a different sort of response than either Stump's or the one I'll propose in the remainder of this paper. For my part, I won't pursue this possibility further here for two main reasons. First, I consider Molinism implausible. I find persuasive the criticisms voiced against it in Adams 1977; Rogers 2008, 148-152; Grant 2019, 126-28 and elsewhere. But Molinists respond to these and other objections in ingenious ways, and I certainly cannot prosecute an effective case against their view here. Second, however, it is unclear to me whether Molinists can subscribe to DUC, or whether they would wish to. Contemporary Molinists sometimes distinguish between "strong" and "weak" actualization and suggest that God only "causes" free choices or actions in the sense of weakly actualizing them (see Plantinga 1974, 173 and Flint 1998, 111). Since "causation" is sometimes suggested as equivalent to "strong actualization" it may be that these contemporary Molinists would reject the notion that God causes creaturely choices or actions, and hence reject DUC. At any rate, readers can proceed with the knowledge that I haven't ruled out the possibility of Molinism providing proponents of DUC with a different and superior response to PPH then what I'll suggest in the following section. 


\section{A Quiescence-Based Choice Model for Proponents of Divine Universal Causality}

My proposal hinges on the claim that even if God causes every act of every created person, nevertheless the created persons can be praised or blamed for their actions. For example, if a created person decides to rebel against God, even if that person cannot do so without God's concurring causally with their decision, they may nevertheless be blamed for it. Suppose, then, that God brings all humans at some stage of their lives to a point where they aren't actively rebelling against him. From this point of non-rebellion, suppose furthermore that some created persons turn to actively resisting God's grace while others persist in non-rebellion. Because we are supposing that God has done just as much for the both groups - bringing both to a point where they are not actively resisting his grace - the fact that the former group turns (or returns) to rebellion while the latter does not might represent a reason for God to provide the latter further gracious assistance that he withholds from the former. This lack of assistance might explain why some humans persist in rebelling against grace until, ultimately, they end up in hell. Yet it needn't represent an arbitrary decision on God's part. Rather, it might be predicated upon certain humans' decisions to return to active rebellion against him. This, then, might provide proponents of DUC with a way of solving PPH.

To illustrate how my proposal might work, consider first two angels at the very first moment of creation. On one widely-held medieval view, angels were not granted beatitude straightaway after they were created in order that, having chosen to accept beatitude as a gracious gift from God, they might merit it - see Pini 2013 for discussion of this view in Anselm, Aquinas and Scotus. Instead of making this meritorious choice, however, some angels like Lucifer straightaway decided instead that they wanted beatitude to some extent or in some way unbefitting their natures. Grasping wrongly for beatitude, these angels rebelled against God, committing what is sometimes called the primal sin. Now proponents of DUC should acknowledge, I think, that God could have prevented this primal sin if he had wanted to. He might have done so, for instance, by granting 
all angels beatitude at the very first moment they were created. Or if he wished to delay their beatitude, he could simply have caused every angel to make the meritorious choice to accept beatitude as a gracious gift in the way they were meant to. We might well wonder why God didn't forestall the primal sin in one of these ways. Setting that wonderment aside, however, it seems as though God did just as much for Gabriel at the moment of creation as he did for Lucifer. That is, he created both of them with abundant knowledge and with powers of intellect and will as yet unexercised. When Lucifer immediately thereafter decides to go after beatitude in some illicit way God concurs causally with his rebellious choice, just as he does with Gabriel's acceptance of beatitude as a gracious gift. Again, God didn't have to do so. But having done so and allowed Lucifer's rebellion, it seems not unreasonable for him to punish Lucifer for having made the choice he did. It is true that Lucifer could not rebel unless God caused him to do so. But proponents of DUC who are compatibilists will claim that God's determining a creature to act a certain way doesn't remove the creature's responsibility for their action, even if they could not have done otherwise. There are also libertarian proponents of DUC, who hold that God's causing a creaturely action does not determine it, and in fact is compatible with the possibility of the creature's having done otherwise (see Grant 2019, chap. 4 along with Koons 2002 and McCann 1995). These will deny that God's causing Lucifer's act of rebellion in any way removed Lucifer's power to choose beatitude as a gift of grace instead. Either way, regardless of whether one prefers a libertarian or compatibilist version of DUC, one can maintain that Lucifer is responsible for his rebellious choice, and that there exists a reason for God to treat him differently from non-rebellious angels like Gabriel.

Now humans are not angels, it's true, but my proposal for solving PPH essentially involves God's returning all humans to a state importantly similar to Gabriel and Lucifer's state at the at the first moment of creation in the story I just told. Many Christians take the doctrine of original sin to imply that unlike angels at the very first moment of creation, all humans begin their lives in a state of active rebellion against God, or at least are born disposed to rebel more or less as soon as they will any- 
thing at all. But even if original sin ensures that all humans spend some period of their lives in active rebellion against God, it nevertheless seems possible to me that God might at some other point in their lives cause all humans to cease actively resisting his grace, whether by accepting it at least by entering a state of quiescence. If God does this at some point for all of us, then presumably for at least some amount of time afterwards it will remain an option available to us to lapse from our acceptance or quiescence to a state of active rebellion against God. If DUC is correct, then for this to happen, God would have to concur causally with our rebellious choices. Nevertheless, it seems to me, if for some pair of humans God has done an equal amount of causal work bringing them to a point where they are either accepting his gracious assistance, or at least quiescent and not actively resisting it, and one of these humans returns to rebellion while the other doesn't, we might say the same as we did regarding Lucifer and Gabriel above. That is, we might judge that God has a good reason for further assisting the one who persists in non-rebellion in ways he doesn't assist the other.

Here is a further illustration of how this proposal might work, drawing upon one that Stump employs. One way of interpreting the conversion story Augustine narrates in Confessions book eight, Stump thinks, is as a story of Augustine's entering a first a state of quiescence before ultimately being moved by God to accept his gracious assistance. Augustine has listened to multiple narratives inclining him toward converting and accepting life of celibacy. Yet he is torn between this higher-order inclination and his lingering lower-order concupiscent desires. This is the state we find him in when he leaves Alypius to weep alone in the garden. As Stump puts it, "[t]he weeping seems to have been an expression of the conflict in his mind and of the accompanying stymied quiescence of the will, which was not able either to reject celibacy or to assent to it either" (Stump 2003, 400-1). After this Augustine hears the child's voice singing "take up and read!" which he takes as a command from God to open the scriptures. Upon reading the first verse he sees, he is finally able to assent to conversion and moral reformation. Suppose for the sake of argument that this interpretation of Augustine's story is roughly cor- 
rect. And now imagine, furthermore, that Augustine has a twin brother whose life story has very closely paralleled Augustine's own. Both have struggled throughout their lives with sexual addiction, but lately through the testimonies of their friends Ambrose, Simplicianus and others, both have found themselves drawn toward their mother's Christian faith and a life of celibacy. Both find themselves deeply moved by Pontitianus's account of Antony, and pray "grant me chastity and continence" (Confessions 8.7.17 in Augustine 1991, 145). Yet they are torn, and add to their prayer, "but not yet." Both rush from Alypius to weep alone in the garden, and find themselves in the state of "stymied quiescence of the will" that Stump describes. At this point, however, some time elapses. And Augustine's brother gets to thinking that he not only doesn't want chastity just yet, but also doesn't really want it at all. At some point before Augustine himself hears the child's voice his brother gets up and tells Alypius he's had enough of the country. He heads back to Milan and immediately visits his favorite den of iniquity. In contrast, we already know what happens with Augustine himself. My claim is that if Augustine stays quiescent while his brother returns to active rebellion against God, that decision on his brother's part would give God a reason for withholding further grace from the brother that he extends to Augustine himself, who hears the child's voice, reads the scriptures, and has "a light of relief from all anxiety flooded into [his] heart" (Confessions 8.12.19 in Augustine 1991, 153).

Now just in the case of Lucifer and Gabriel above, I think proponents of DUC should acknowledge that God could have caused both Augustine and his brother in this scenario to remain quiescent, and to accept the subsequent grace he extends. If Augustine's brother ends up in hell, I do not intend for the story I've just told to provide us any explanation why he ends there as opposed to joining Augustine in heaven. It is not a solution to GPH. What the story does explain, I am proposing, is why Augustine's brother might end up in hell as opposed to Augustine himself ending up there, hence providing a solution to PPH. Again, the reason is based upon their divergent responses to having been offered an equal measure of divine assistance. I will now consider four objections that one might raise against this proposal. 
First, one might argue that God couldn't possibly bring all created persons out of the original sin into which they're born to a point of non-rebellion, as I have proposed he might do. One might point out, perhaps, that this would be impossible to do for humans who die as infants. I would reply to this by conceding that I don't share Augustine's certainty about the fates of those who die as infants. I'm not sure what will happen to them, and I'm happy to limit my proposal to humans without cognitive disabilities who live into adulthood.

Second, one might argue that given the diversity of humankind, it is impossible for God to provide precisely the same measure of assistance to all humans. Because they come from such disparate starting points, God will have to assist some more than others to reach a point of non-rebellion, and hence arbitrariness is inevitable. Perhaps it is true that to bring humans from the sinful origins they begin with to a point where they accept (or at least don't resist) his grace he will have to assist them in different and unequal ways. I don't think this matters, however, as regards the success or failure of my solution to PPH. My proposal simply requires that God provide an equal measure of assistance to each human in the sense that he brings each of us at least once in our lives from the original sin into which we're born to a point of non-resistance to his grace. It doesn't matter especially what measures he takes to accomplish this, or how often he does so. It may be indeed that God renders greater assistance to some who ultimately choose to reject him. He might, for instance, bring them from active rebellion to acceptance or quiescence multiple times throughout their lives, only to have them relapse repeatedly. All my proposal requires, I think, is that God provides at least as much assistance to those who ultimately end up choosing rebellion and hell as to those who ultimately end up accepting grace and glory.

A third objection might note that it certainly doesn't seem as though all persons cease rebelling at some point in their lives. It is true, I would acknowledge, that some appear to resist God all throughout their lives. But appearances can deceive, and only God knows the hearts of men. Even hardened sinners might soften momentarily in private, reaching 
a point of non-resistance toward God's aid, even if they aren't yet accepting it. That is all my proposal requires.

The reason I think Stump's Thomistically-inspired notion of quiescence in the will is useful for my purposes here is largely in order to ward off a fourth objection someone might raise, alleging that God does not in fact provide the same measure of assistance to Lucifer and Gabriel or $\mathrm{Au}$ gustine and his brother in the stories I told above. In fact, someone might say, God provides additional aid to Gabriel and to Augustine in their respective scenarios insofar as he causally upholds them in their state of non-rebellion during the same moment at which he ceases doing so for Lucifer and Augustine's brother. This might, I think, be a legitimate worry about my proposal if indeed I were to suggest that God brings all humans, for instance, from an initial state of rebellion to one of accepting his grace, but then upholds only some in this state of positively willing to accept grace while ceasing to cause it others, and causing instead a return to rebellion. If, however, God brings us all to just to a point of quiescence, then perhaps the worry can be assuaged. As I understand Stump's notion of quiescence, someone in this state retains their power of will, yet the power is inactive with respect to some given option - willing neither for nor against it. Returning to the case of Augustine and his twin with this in mind, it seems to me that at the moment the brother returns to active rebellion God is still causally upholding both in the exact same way insofar as he is sustaining in both their power of will. It is true that at that moment God is also causing in Augustine's brother a positive act of choosing to return to rebellion, whereas he isn't causing such a choice in Augustine himself. But since God is merely concurring causally with the brother's own decision, it isn't as though he causes the return to rebellion arbitrarily. Nor is God providing anything additional to Augustine that he is withholding from the twin. Again, he is causally upholding the power of willing in both. The following chart illustrates what I take to be the divine and human causal contributions in the scenario I've been discussing: 


\begin{tabular}{|c|c|c|c|c|}
\hline Causes & Time T1 & Time T2 & Time T3 & Time T4 \\
\hline $\begin{array}{l}\text { Augustine } \\
\text { causes: }\end{array}$ & $\begin{array}{l}\text { A choice to } \\
\text { reject God's } \\
\text { grace }\end{array}$ & $\begin{array}{l}\text { No choice - } \\
\text { quiescence }\end{array}$ & $\begin{array}{l}\text { No choice - } \\
\text { quiescence }\end{array}$ & $\begin{array}{l}\text { A choice } \\
\text { to accept } \\
\text { God's grace }\end{array}$ \\
\hline $\begin{array}{l}\text { The twin } \\
\text { causes: }\end{array}$ & $\begin{array}{l}\text { A choice to } \\
\text { reject God's } \\
\text { grace }\end{array}$ & $\begin{array}{l}\text { No choice - } \\
\text { quiescence }\end{array}$ & $\begin{array}{l}\text { A choice to } \\
\text { return to re- } \\
\text { bellion }\end{array}$ & $\begin{array}{l}\text { A choice } \\
\text { to reject } \\
\text { God's grace }\end{array}$ \\
\hline $\begin{array}{l}\text { God causes } \\
\text { in Augustine: }\end{array}$ & $\begin{array}{l}\text { - A choice to } \\
\text { reject grace } \\
\text { - The power } \\
\text { of willing }\end{array}$ & $\begin{array}{c}\text { - The power } \\
\text { of willing }\end{array}$ & $\begin{array}{l}\text { - The power } \\
\text { of willing }\end{array}$ & $\begin{array}{l}\text { - The power } \\
\text { of willing } \\
\text { - A choice to } \\
\text { accept grace }\end{array}$ \\
\hline $\begin{array}{l}\text { God causes } \\
\text { in the twin: }\end{array}$ & $\begin{array}{l}\text { - A choice to } \\
\text { reject grace } \\
\text { - The power } \\
\text { of willing }\end{array}$ & $\begin{array}{c}\text { - The power } \\
\text { of willing }\end{array}$ & $\begin{array}{l}\text { - The power } \\
\text { of willing } \\
\text { - A choice to } \\
\text { reject grace }\end{array}$ & $\begin{array}{l}\text { - The power } \\
\text { of willing } \\
\text { - A choice to } \\
\text { reject grace }\end{array}$ \\
\hline
\end{tabular}

In this chart time $\mathrm{T}_{1}$ is some earlier point in the lives of Augustine and his brother when both are still resisting conversion. Time $\mathrm{T}_{2}$ represents the point at which God moves both to cease rejecting grace, though not yet to accept it either - both are in a state of quiescence. At $\mathrm{T}_{3}$ the twin, but not Augustine, has returned to rebellion, and is once again rejecting grace. He is still doing so at $\mathrm{T}_{4}$, whereas by this point God has moved Augustine himself to accept his assistance in the process of moral reformation. My claim is that while it is true that God causes something different in the twin than he does in Augustine at points $\mathrm{T}_{3}$ and $\mathrm{T}_{4}$, there is a reason for this, namely the twin's choice and the corresponding absence of choice on Augustine's part at $\mathrm{T}_{3}$. If this is correct, then Stump's notion of quiescence in the will can indeed help explain how God might non-arbitrarily decide between those to whom he'll grant further grace and those from whom he'll withhold it.

The solution to PPH that I have argued for in this section might be viewed as a kind of Choice Model, in that it bases God's decision to allow the particular set of created persons to occupy hell that he does on choices made by these persons. Specifically, he bases his decision on these persons' choice to return to active rebellion against him after having been 
brought by him to a point of non-rebellion. By my lights a Choice Model is preferable to "biting the bullet" like Aquinas does, and conceding that God's decision whom to predestine and whom to reprobate is ultimately arbitrary. I hope to have shown that a kind of Choice Model is available to proponents of DUC, at least far as PPH is concerned. Since, however, my proposal does not purport to provide any solution to GPH, more work remains to be done for proponents of DUC interested in formulating a comprehensive response to the Problem of Hell. ${ }^{1}$

\section{References}

Adams, Robert Merrihew. 1977. "Middle Knowledge and the Problem of Evil." American Philosophical Quarterly 14.2: 109-117.

Augustine. 1991. Confessions. Translated by Henry Chadwick. Oxford: Oxford University Press.

Augustine. 1999. De dono perseverantiae. Translated by Roland Teske in Answers to the Pelagians IV, edited by John Rotelle. Hyde Park, NY: New City Press.

Flint, Thomas P. 1998. Divine Providence: The Molinist Account. Ithaca, NY: Cornell University Press.

Grant, W. Matthews. 2019. Free Will and God's Universal Causality: The Dual Sources Account. London: Bloomsbury.

Koons, Robert. 2002. "Dual Agency: A Thomistic Account of Providence and Human Freedom.” Philosophia Christi 4.2: 397-410.

Kvanvig, Jonathan L. 2011. Destiny and Deliberation: Essays in Philosophical Theology. Oxford: Oxford University Press.

McCann, Hugh. 1995. "Divine Sovereignty and Freedom of the Will." Faith and Philosophy 12.4: 582-98.

Pini, Giorgio. 2013. "What Lucifer Wanted: Anselm, Aquinas and Scotus on the Object of the First Evil Choice." Oxford Studies in Medieval Philosophy 1: 61-82. Plantinga, Alvin. 1974. The Nature of Necessity. Oxford: Oxford University Press. Rogers, Katherin. 2008. Anselm on Freedom. Oxford: Oxford University Press. Stump, Eleonore. 1985. “The Problem of Evil.” Faith and Philosophy 2.4: 392-423.

1 This paper is an output of the project "The Problem of Evil: From Leibniz to Analytic Philosophy of Religion” (FFI2017-84559-P: Ministerio de Ciencia e Innovación, Gobierno de España). I am grateful to participants in the 2019 "Nature and Limits of Theodicy" seminar at the Universidad de Navarra for their helpful commentary on an earlier draft, and especially to Agustín Echavarría for organizing it. 
Stump, Eleonore. 1986. “Dante's Hell, Aquinas's Moral Theory and the Love of God.” Canadian Journal of Philosophy 16.2: 181-98.

Stump, Eleonore. 1988. "Sanctification, Hardening of Heart and Frankfurt's Concept of Free Will.” The Journal of Philosophy. 85.8: 395-420.

Stump, Eleonore. 2001. "Augustine on Free Will.” In The Cambridge Companion to Augustine, edited by Stump and Norman Kretzmann, 124-47. Cambridge: Cambridge University Press.

Stump, Eleonore. 2003. Aquinas. London: Routledge. 